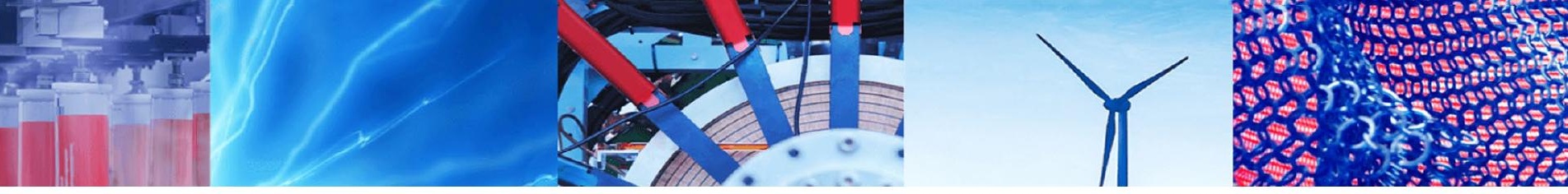

Research Article

\title{
Projected temperature increases over northern Ghana
}

\author{
Nana Ama Browne Klutse ${ }^{1} \cdot K_{w a d w o}$ Owusu ${ }^{2}$ (D) Yaw Agyeman Boafo ${ }^{3}$
}

Received: 27 November 2019 / Accepted: 16 June 2020 / Published online: 6 July 2020

(c) Springer Nature Switzerland AG 2020

\begin{abstract}
This study reports on projected temperature increases and their likely implication on smallholder farming systems across the northern regions of Ghana. Aggregated climate data from 1961 to 2000 show that the mean annual temperature across Ghana rose by $1.0^{\circ} \mathrm{C}$, with the greatest rate of change in the northern-eastern part of the country. For the development of the downscaled climate projection, five regional climate models (RCMs) forced with three global climate models (GCMs) were used from CORDEX and CMIP5, respectively. Eight stations spatially spread across the study locations were selected for the study based on the quality and completeness of data. The study used daily, minimum and maximum temperature station data from 1980 to 2014 obtained from the Ghana Meteorological Agency. The downscaling was done for the emission scenarios pathways-Representative Concentration Pathways (RCP) 2.6 and 8.5-from the selected RCMs using the station data. Time series of minimum and maximum temperatures averaged for the eight stations was analysed from 1961 to 2080 . Results indicate temperatures are likely to increase over northern Ghana with minimum air temperature increasing by $0.5^{\circ} \mathrm{C}$ under RCP 2.6 and $2.5^{\circ} \mathrm{C}$ under RCP 8.5. Maximum air temperatures are likely to increase by $1{ }^{\circ} \mathrm{C}$ under RCP 2.6 and $2^{\circ} \mathrm{C}$ under RCP 8.5 by the year 2080 . Warming rates per year for the stations reveal that minimum temperatures are warming faster than maximum temperatures. The 99 th percentile, which is a measure of heat waves, shows a close relationship between the minimum temperatures for the RCP 2.6 and RCP 8.5 pathways in all the stations except for Wenchi and Bolgatanga. Each pathway has a variation between $22.5^{\circ} \mathrm{C}$ and $30^{\circ} \mathrm{C}$. The lowest projected value of the 99 th percentile maximum temperature is $35^{\circ} \mathrm{C}$ in Wenchi, and the highest projected is above $43^{\circ} \mathrm{C}$ in Navrongo. Smallholder food crop farming systems are likely to be negatively impacted, with direct risks of low crop yield unless measures like irrigation and careful crop selection are implemented.
\end{abstract}

Keywords Minimum temperature $\cdot$ Maximum temperature $\cdot$ RCP $2.6 \cdot \operatorname{RCP} 8.5 \cdot$ Northern Ghana

\section{Introduction}

A key outcome of the 2015 Paris Agreement was the objective of "holding the increase in the global average temperature to well below $2{ }^{\circ} \mathrm{C}$ above pre-industrial levels and pursuing efforts to limit the temperature increase to $1.5^{\circ} \mathrm{C}^{\prime \prime}$ [47]. This effort is a recognition that the current and projected elevation of atmospheric carbon means global temperature will continue to rise. Global temperature increases are expected to significantly impact various regions of the world [18], and the effect will be devastating for rainfed agriculture systems [9-11] which dominates the developing world mostly in the low-latitude tropical regions [19]. The high reliance of smallholder farmers on rainfed agriculture makes them prone to climate-related shocks and stresses $[7,9,15]$. Among the numerous threats

Electronic supplementary material The online version of this article (https://doi.org/10.1007/s42452-020-3095-3) contains supplementary material, which is available to authorized users.

$\triangle$ Kwadwo Owusu, kowusu@ug.edu.gh | 'Department of Physics, University of Ghana, P.O. Box LG64, Legon, Ghana. ${ }^{2}$ Department of Geography and Resource Development, University of Ghana, Legon, Ghana. ${ }^{3}$ Center for Climate Change and Sustainability Studies, University of Ghana, Legon, Ghana. 
faced by smallholder farmers, exposure to extreme heat is one of the most serious health risks that can potentially inhibit their work and consequentially affect their productivity [21]. Given the fact that developing countries, especially those in Sub-Saharan Africa (SSA), have low adaptive capacity, there is often poor or lack of the needed information that forms the basis for climate decision-making including adaptation $[23,34,37,44]$. With global warming, West Africa is projected to have a continuous and stronger warming (up to $6.5^{\circ} \mathrm{C}$ ), higher than the projected average global temperature of $1.5^{\circ} \mathrm{C}$ by the year 2100 [45].

In Ghana, climate projections are in line with global assessments and tend to agree that temperatures will continue to rise [6, 26]. The projections by Stanturf et al. [43] were that mean temperature increases in the dry season between $1.5^{\circ} \mathrm{C}$ and about $3.0^{\circ} \mathrm{C}$ by 2080 in most agro-ecological zones. Similarly, the Government of Ghana projects an increase in average annual temperature of up to $0.8^{\circ} \mathrm{C}$ by 2020 and $5.4{ }^{\circ} \mathrm{C}$ by 2080 , across all agro-ecological zones $[27,30]$. There is also a strong spatial variation in the projected temperatures with the northern Ghana (above $8^{\circ} \mathrm{N}$ ) expected to experience a greater rate of warming than the coastal areas of the country $[5,29,48]$.

According to Ghana's Third National Communication, the northern half of Ghana will continue to be more vulnerable to climate change impacts [26]. The northern half of Ghana has been found by numerous studies to be the most vulnerable and exposed to climate change impacts due to factors such as lack of information about impending natural disasters, fluctuations in precipitation and temperature, poverty and illiteracy among others which increase the region's sensitivity to climatic extremes [1, 40, 50]. MESTI [26] reported the observed changes in a decade for minimum temperatures to be $20 \%$ and the maximum temperature to be $29.6 \%$ for the northern parts of Ghana.

At the local scale, it is important to estimate the magnitude of future warming using regional downscaling methods to aid in adaptation planning. Downscaling methodology usually from GCMs is a necessary approach for obtaining high-resolution and detailed climate simulations that can be used in the development of effective adaptation strategies at regional and sub-regional scale. In this approach, we assume that large-scale weather strongly influences the local-scale weather but not the reverse [17, 3]. In this paper, the Coordinated Regional Climate Downscaling Experiment (CORDEX) that produces dynamically downscaled climate simulations for all continents has been adopted for analysis of future climate projections. CORDEX is also filling the gap of the lack of local capacity in many regions, especially in Africa (CORDEX-Africa; [33]. It is hoped that the downscaling process will have minimal uncertainties to be useful for adaptation planning. This study sought to assess the likely temperature increases over northern Ghana using CORDEX-Africa models. The aim is to provide finer climate information to aid adaptation planning for smallholder agriculture production in climate change vulnerable landscapes of northern Ghana. The vast majority of the world's farming population is smallholder farmers, comprising $70 \%$ of farms worldwide [46]. In the context of this study, smallholder farmers are those farmers with less than two hectares of land whose predominant objective is to use the proceeds from their farming activities for household consumption $[8,16]$. Smallholder farmers make up around half of the world's population classified as hungry and three-quarters of persons who are hungry in Africa [10, 41]. The current situation is expected to directly hamper the achievement of sustainable development goals 1 (no poverty) and 2 (zero hunger).

\section{Materials and methods}

\subsection{Study area}

The northern half of Ghana which is the focus of this study lies roughly between latitudes $8^{\circ} \mathrm{N}$ and $11^{\circ} \mathrm{N}$ and longitudes $2.5^{\circ} \mathrm{W}$ and $0.5^{\circ} \mathrm{E}$ as used in Owusu and Klutse [38]. Northern Ghana's rainfall is characterized by a long dry period of about seven months from October/November to April/May called the dry season with no appreciable rainfall level and a rainy season from May to October with adequate levels of rainfall for agricultural production. Temperatures are high and range between $32^{\circ} \mathrm{C}$ and $38^{\circ} \mathrm{C}$ (Ghana Meteorological Agency-GMet [14]. According to the GMet, evapotranspiration is very high and restricts agricultural production, which is almost entirely rainfed to one season a year. Additional increases in temperature with minimal improvement or reduction in rainfall will have a significant impact on crop production in the region.

\subsection{Observed data and quality control}

The study used daily minimum and maximum temperature data obtained from the GMet covering 33 years of records from 1980 to 2014. The data had missing values from 2001 to 2005 when obtained. Eight stations (Atebubu, Bole, Bolgatanga, Navrongo, Tamale, Wa, Wenchi and Yendi) were selected for the study based on the quality and completeness of data. The selected stations, although few, are a good representation of the study area because of their distribution and the fact that the rainfall mechanism is the same [36]. All the other gauge stations in the northern half of Ghana had large data gaps. The stations with at least $80 \%$ data availability were selected for the study. The stations, which did not meet minimum criteria for all 
the relevant variables, were eliminated after being subjected to rigorous quality control checks using RClimdex to eliminate influences in the data other than the climate [51]. RClimdex is a local package in R programme used to conduct simple quality control on the input daily data [51]. All missing values (-99.9), daily maximum temperature less than daily minimum temperature, and outliers in daily maximum and minimum temperature in the data were replaced with not available (NA).

\subsection{Statistical downscaling of global climate models}

For the development of the climate change scenarios, three regional climate models (RCMs), namely Swedish Meteorological and Hydrological Institute (SMHI), CLMcom and REMO from the CORDEX-Africa domain datasets emanating from five global climate models (GCMs), were used in the study. These model data have been used in a number of research studies over West Africa due to their performance over the region (e.g. [22, 32]). The climate change projections were produced by downscaling the simulations of the five GCMs from CMIP5 global climate projections, namely the Max Plank Institute MPI-ESM-LR, National Centre for Meteorological research CNRM-CM5, GFDL-ESM2G of NOAA, CM5A-LR of REMO and MIROC5 of SMHI. The simulations were done for the emission scenarios pathways-Representative Concentration Pathways (RCP) 2.6 and RCP 8.5-for the selected RCMs. The simulated temperature (minimum and maximum) of GCM/ RCMs combination was extracted for each of the eight selected locations in the study area for analysis.

The downscaled RCMs for the selected stations in the study area were transformed such that the magnitude and distribution of the transformed variable come as close to the gauged points [25]. The quantile-quantile statistical technique was applied to make the statistical distribution of the downscaled variables as close as possible to the statistical distribution of historical observations. Further to the quantile-quantile technique, transformation was done for the removal of the residual bias. A delta change correction was applied to allow the downscaled data and the gauge data to have the same mean on the historical period. Time series of minimum and maximum temperatures averaged for the eight (8) stations in the study area was analysed from 1961 to 2080 .

\subsection{Results and discussion}

\subsubsection{Projected mean temperature scenarios}

Figures 1 and 2 show boxplots representing the distribution of the baseline observation data and the model ensemble data for minimum and maximum temperatures for each station. Even though the model ensemble has a wider temperature distribution and a bigger interquartile range for all the stations, ensemble mean and that of the baseline observation show less deviation. The minimum values of the maximum temperature for model and baseline data are about the same for all stations except for Atebubu, but the maximum values differ for all stations. Maximum temperature at Atebubu and Wenchi shows outliers for the baseline. Unlike the maximum temperature, the minimum temperatures for all station baseline have outliers. Beside the outliers, the minimum temperature baseline distribution also lies within the distribution of the model for all stations. Overall, the observed temperature baseline spread lies within the model spread for almost all stations. This implies that the downscaled model dataset generally fits well the minimum and maximum temperature trends of the observed. The models project increases in warm trends for both maximum and minimum temperatures averaged over each station, with similar, though slightly weaker in magnitude towards the end of the twenty-first century.

\subsubsection{Minimum temperature}

For minimum temperatures, almost an increase of $2.5^{\circ} \mathrm{C}$ above that of the present day is projected under RCP 8.5 for all stations, but under RCP 2.6, a projected increase of about $0.5^{\circ} \mathrm{C}$ is expected by the year 2080 (Fig. 3). In terms of spatial patterns, by 2050 , the minimum temperature is projected to increase steadily from south-west of the study area to the northeast under RCP 8.5 (Fig. 4). From Fig. 4, the peak in the northeast spreads to the west and descends in the east down to Tamale under RCP 2.6. The spatial trends projected are consistent with historical temperature trends across the study area $[20,26]$. For Tamale and the south-western part, warmer temperatures are projected under RCP 2.6 than RCP 8.5 in the present day and the future until 2050 where temperature from RCP 8.5 is warmer (Figs. 3, 4). The result agrees with the general increase in minimum temperature over Ghana. According to MESTI [26], the mean monthly minimum temperature is likely to increase by $1.4^{\circ} \mathrm{C}$ by $2040,2.5^{\circ} \mathrm{C}$ by 2060 and $3^{\circ} \mathrm{C}$ by 2080.

\subsubsection{Maximum temperature}

For maximum temperature (Fig. 5), projected increases of about $2^{\circ} \mathrm{C}$ above the present day are projected under RCP 8.5 by 2080 in all stations but are constrained to less than $1^{\circ} \mathrm{C}$ under RCP 2.6. For Tamale and Wenchi, warmer temperatures are projected under RCP 2.6 than RCP 8.5 until 2050. However, towards 2080, maximum temperature is 

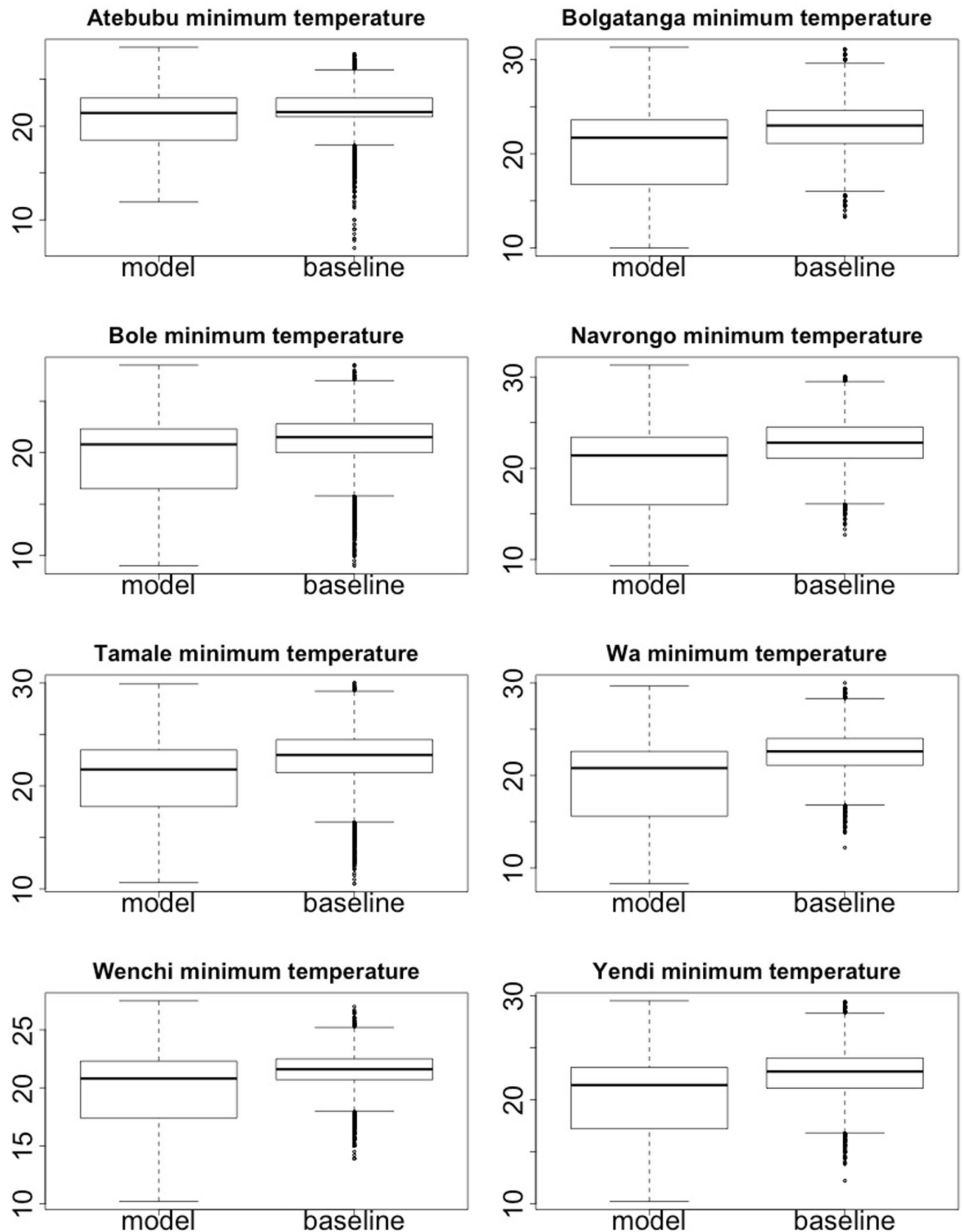

Fig. 1 Minimum temperature of observed baseline and model ensemble data distribution 
Atebubu maximum temperature

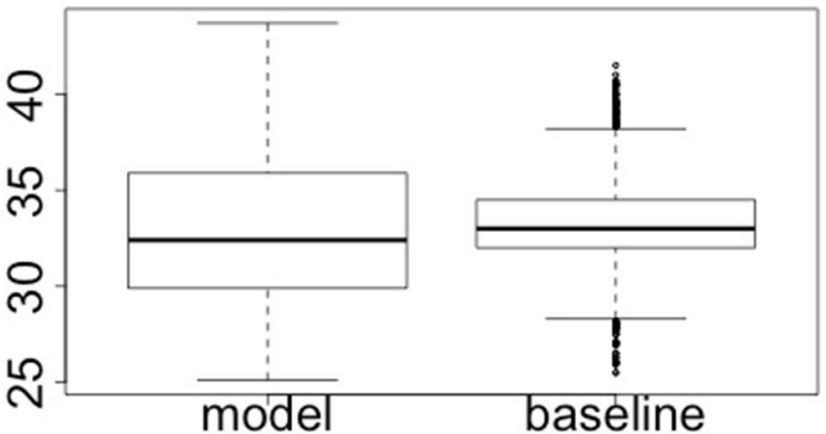

Bole maximum temperature



Tamale maximum temperature

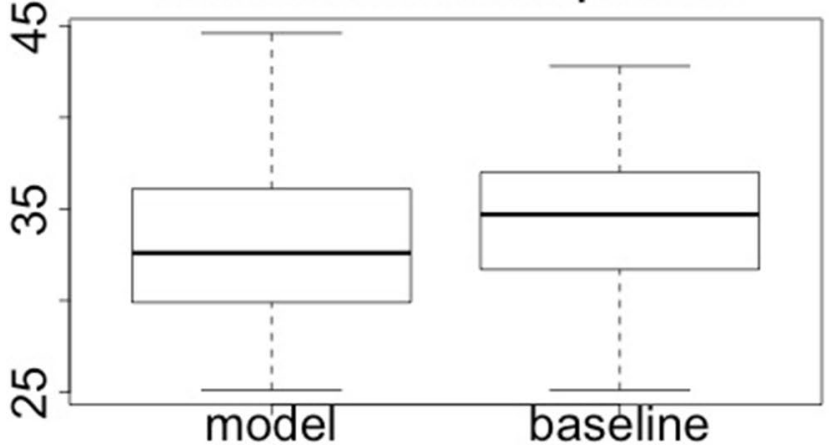

Wenchi maximum temperature

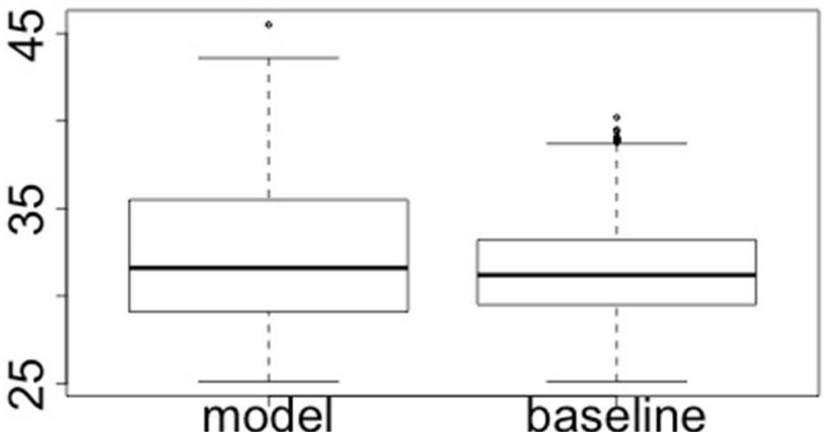

Bolgatanga maximum temperature


Fig. 2 Maximum temperature of observed baseline and model ensemble data distribution 


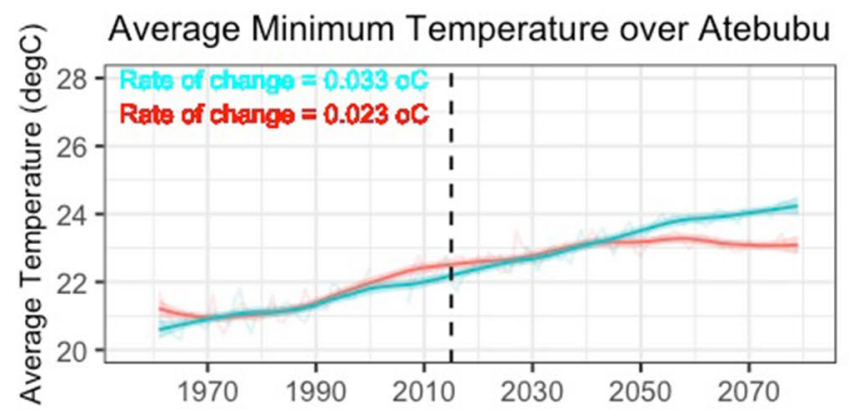

Average Minimum Temperature over Bole
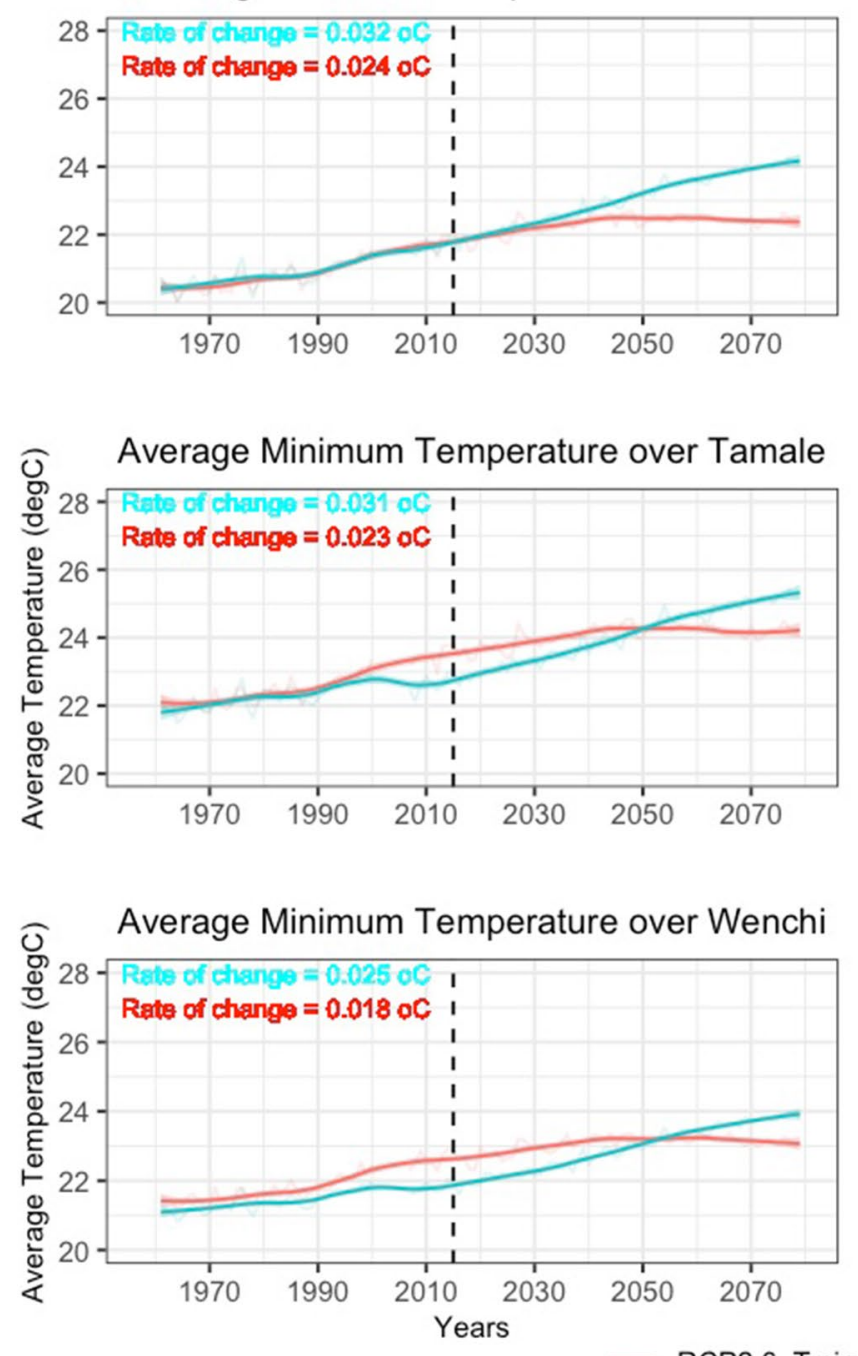

Fig. 3 Time series of averaged minimum temperature between 1961 and 2080 over stations in the study area for the RCP2.6 (orange) and RCP8.5 (purple). Dashed lines represent the bound-

projected to be warmer in RCP 8.5 than RCP 2.6. Consistent with the minimum temperatures, the north-eastern corner of the country is projected to experience greater warming by 2080 (Fig. 6). The results agree with IPCC [18]

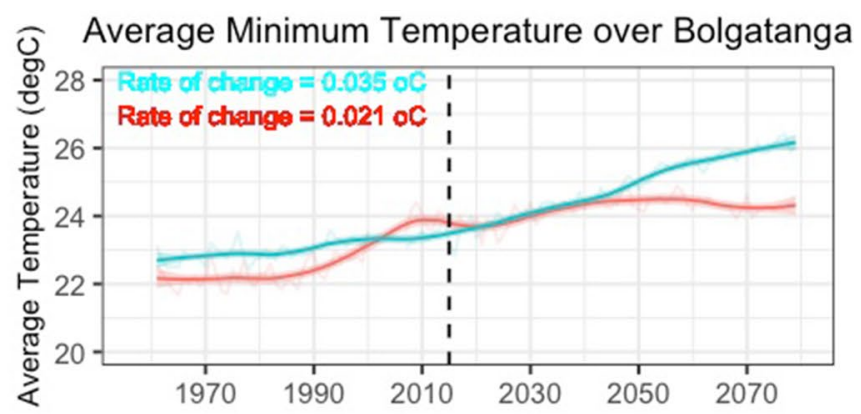

Average Minimum Temperature over Navrongo

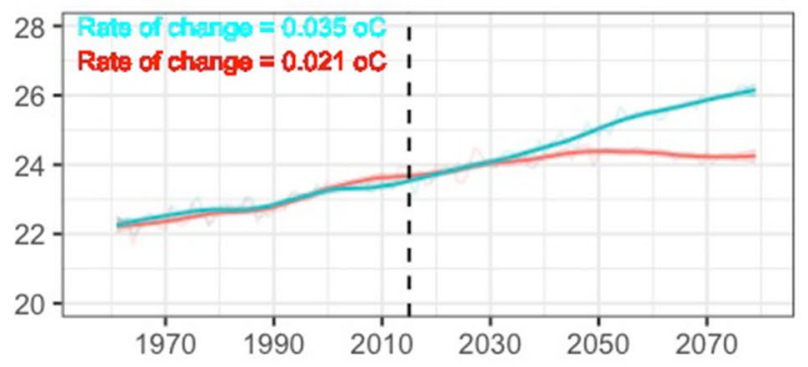

Average Minimum Temperature over Wa

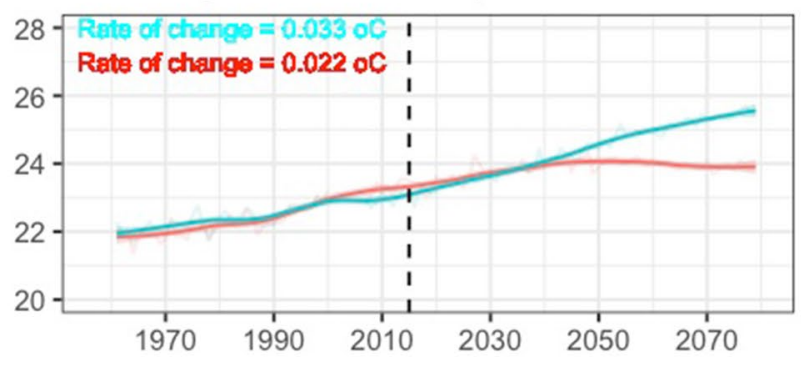

Average Minimum Temperature over Yendi

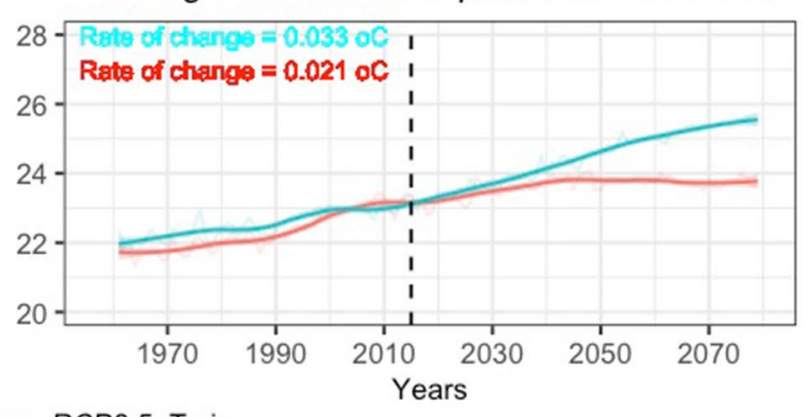

RCP8.5_Tmin

ary between the present day and future trends. The rate of change (plots in supplementary materials) is indicated on the upper left corner of the figure. Colours refer to the pathways

that temperature has risen by almost a degree over the last century and is projected to accelerate over the next 50 years, resulting in an increase of further $1.5-3^{\circ} \mathrm{C}$ of warming. MESTI [26] also reports that the mean monthly 

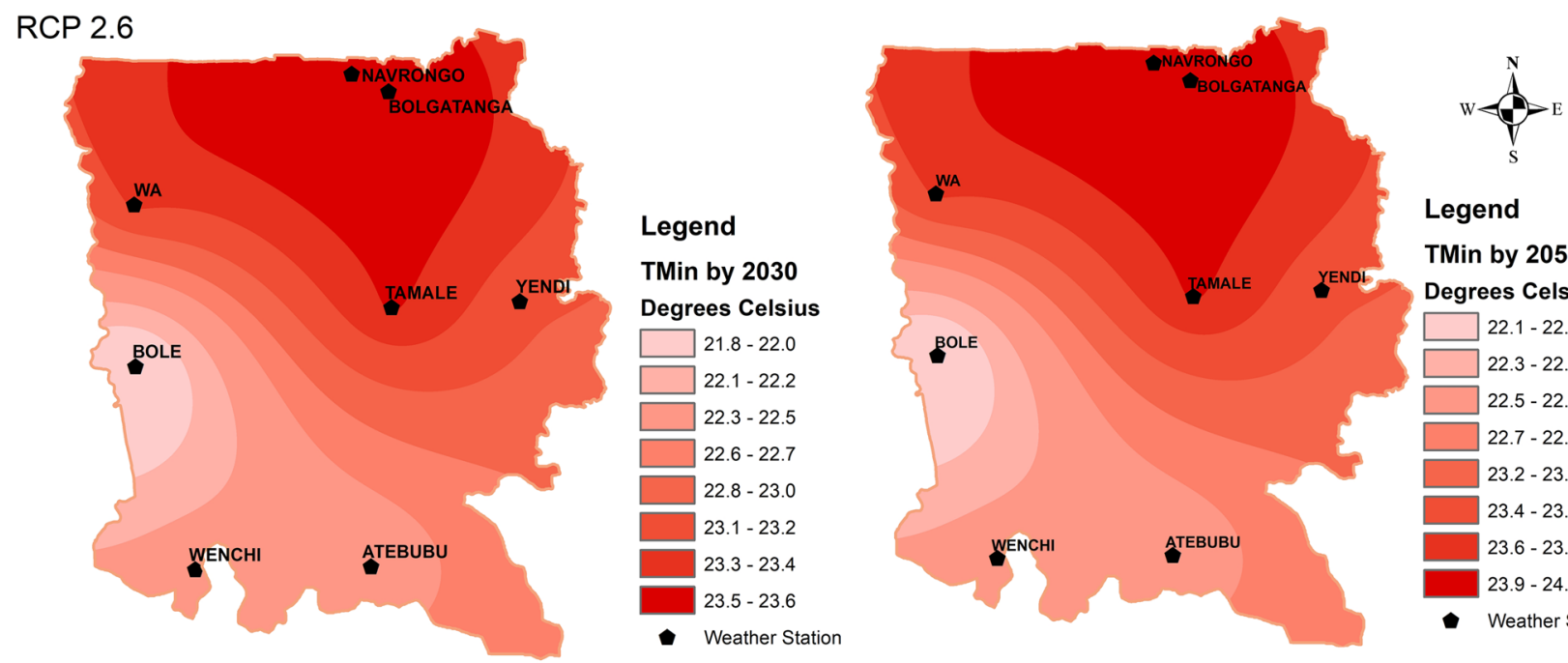

Legend

RCP 8.5
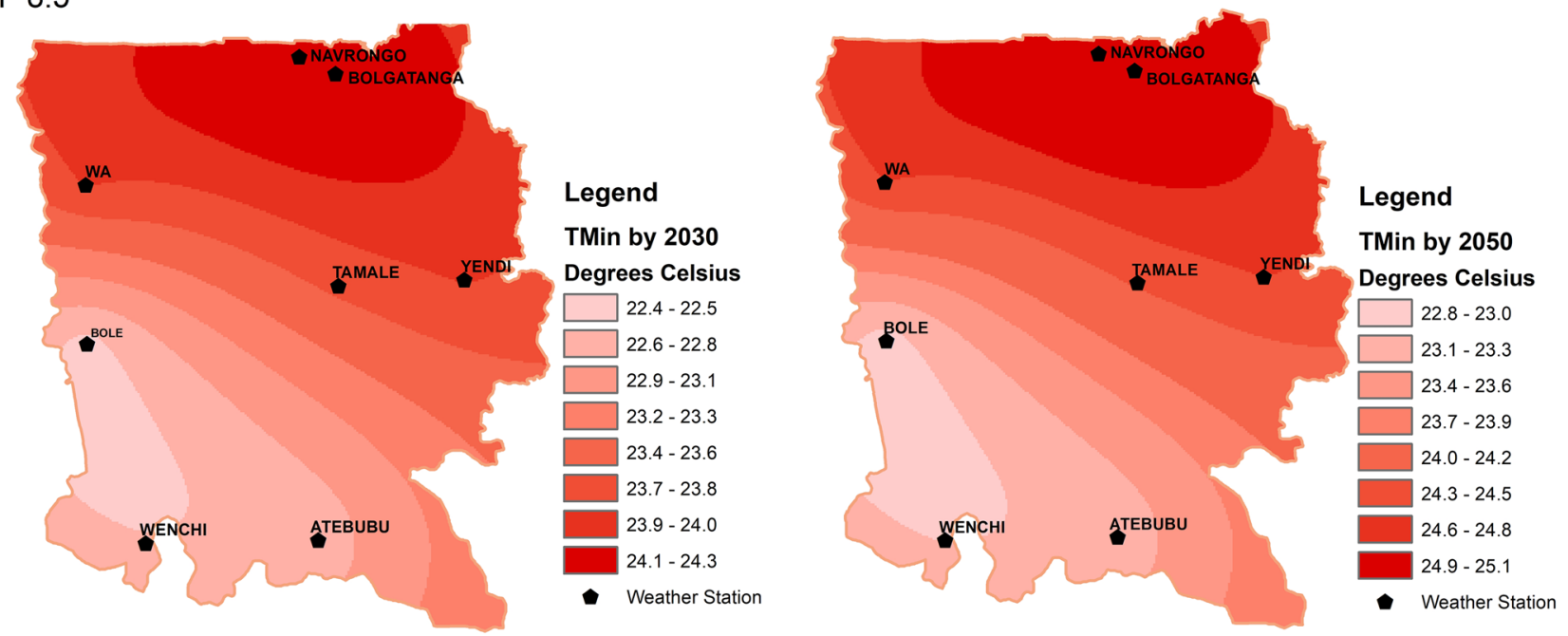

Fig. 4 Averaged minimum temperature for 2030 and 2050 in the study area for the RCP2.6 and RCP8.5 scenarios

maximum temperature is most likely to record an increase of $1^{\circ} \mathrm{C}$ by the year $2040,1.9^{\circ} \mathrm{C}$ by 2060 and $2.5^{\circ} \mathrm{C}$ by the year 2080 .

\subsection{Projected warming rate of minimum and maximum temperatures}

All stations showed positive rate of change projected per year for minimum and maximum temperatures (Figs. 3 and 5). The stations have a different rate of change under different emission pathways, but some stations have same rate of change under the same scenario. For example, minimum temperature under RCP 2.6 shows that Bole, Yendi and Navrongo have the same rate of change of an average value of $0.021{ }^{\circ} \mathrm{C}$ per year. The lowest warming rate is $0.018^{\circ} \mathrm{C}$ at Wenchi, and the highest warming rate is $0.024{ }^{\circ} \mathrm{C}$ at Bolgatanga. For each station, RCP 8.5 presents a higher rate of warming than the RCP 2.6. Wenchi is likely to have the lowest warming rate of minimum temperature at a rate of $0.025^{\circ} \mathrm{C}$ under the RCP 8.5. The highest warming rate of minimum temperature will likely be at Navrongo and Bolgatanga with each station projecting $0.035^{\circ} \mathrm{C}$ per year under RCP 8.5. The warming rate of maximum temperature is likely to be in the range from $0.014{ }^{\circ} \mathrm{C}$ to $0.016{ }^{\circ} \mathrm{C}$ per year under RCP 2.6 and $0.025{ }^{\circ} \mathrm{C}$ to $0.029{ }^{\circ} \mathrm{C}$ per year under RCP 8.5. The increasing trend of temperature over a part of the study area was reported by Kranjac-Berisavljevic [24] study, which did a comparative analysis of mean temperature from the period 1931-1990 in the Upper East Region. Similarly, Frimpong et al. [13] reported that Bawku East district of the Upper East Region of Ghana has had an increased temperature rate of $0.075^{\circ} \mathrm{C}$ per year for the period 1961 to 2012 which is above the 


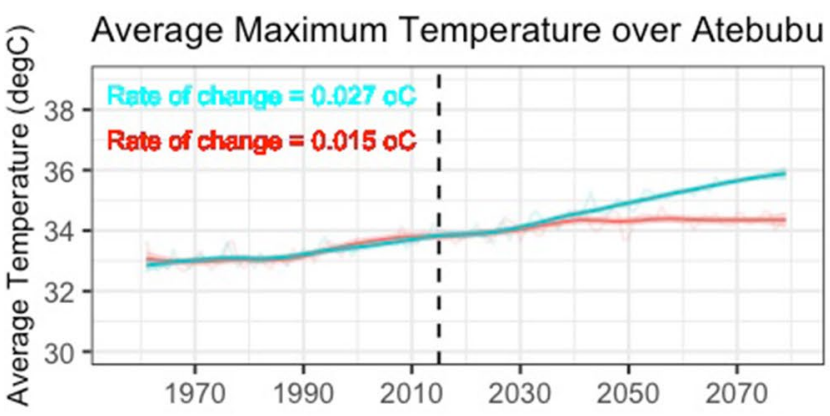

Average Maximum Temperature over Bolgatange

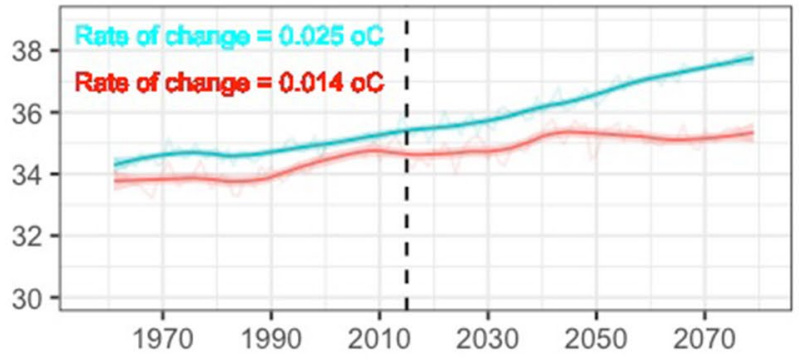

Average Maximum Temperature over Bole



Average Maximum Temperature over Navrongo
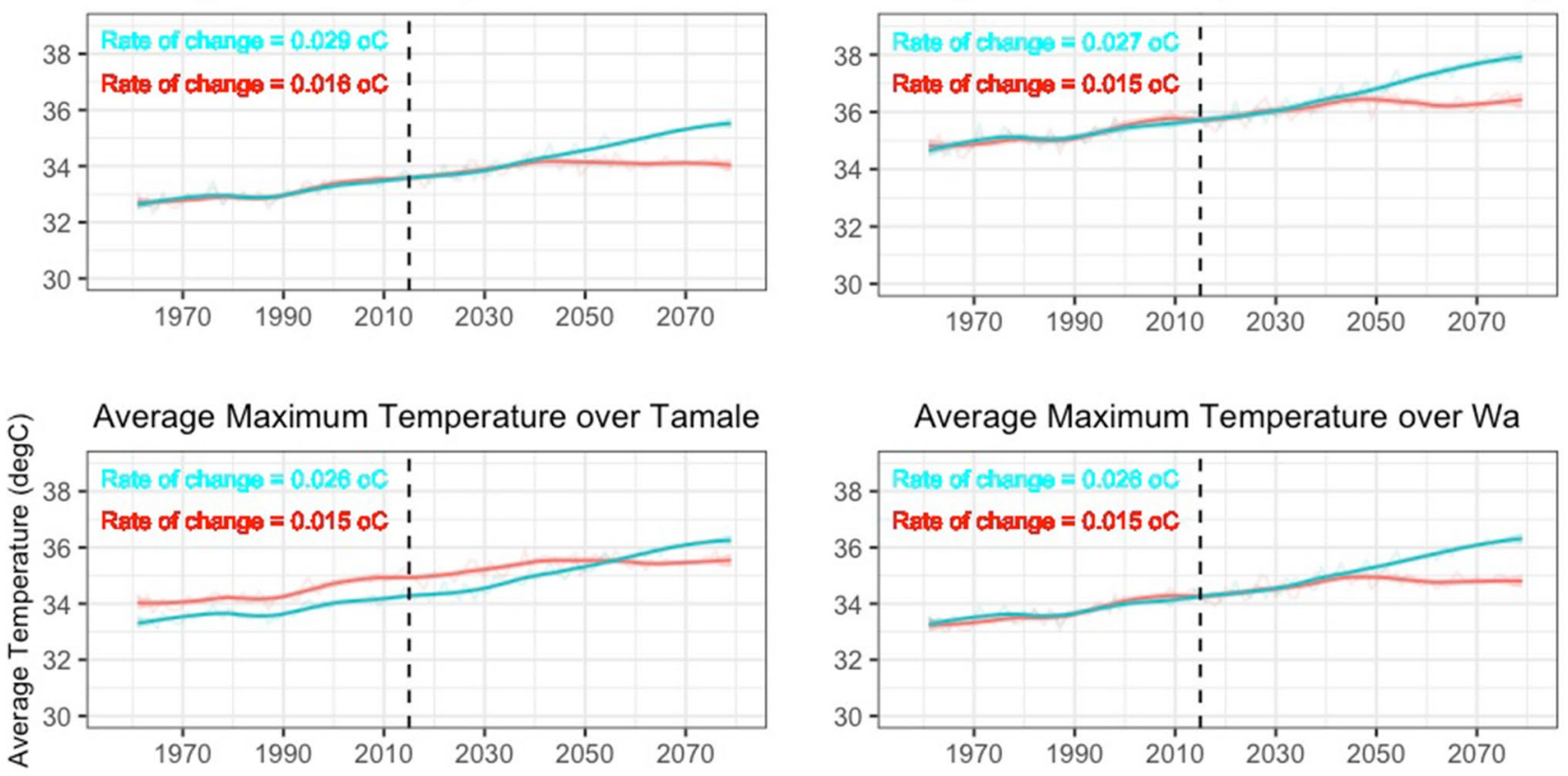

Average Maximum Temperature over Wa
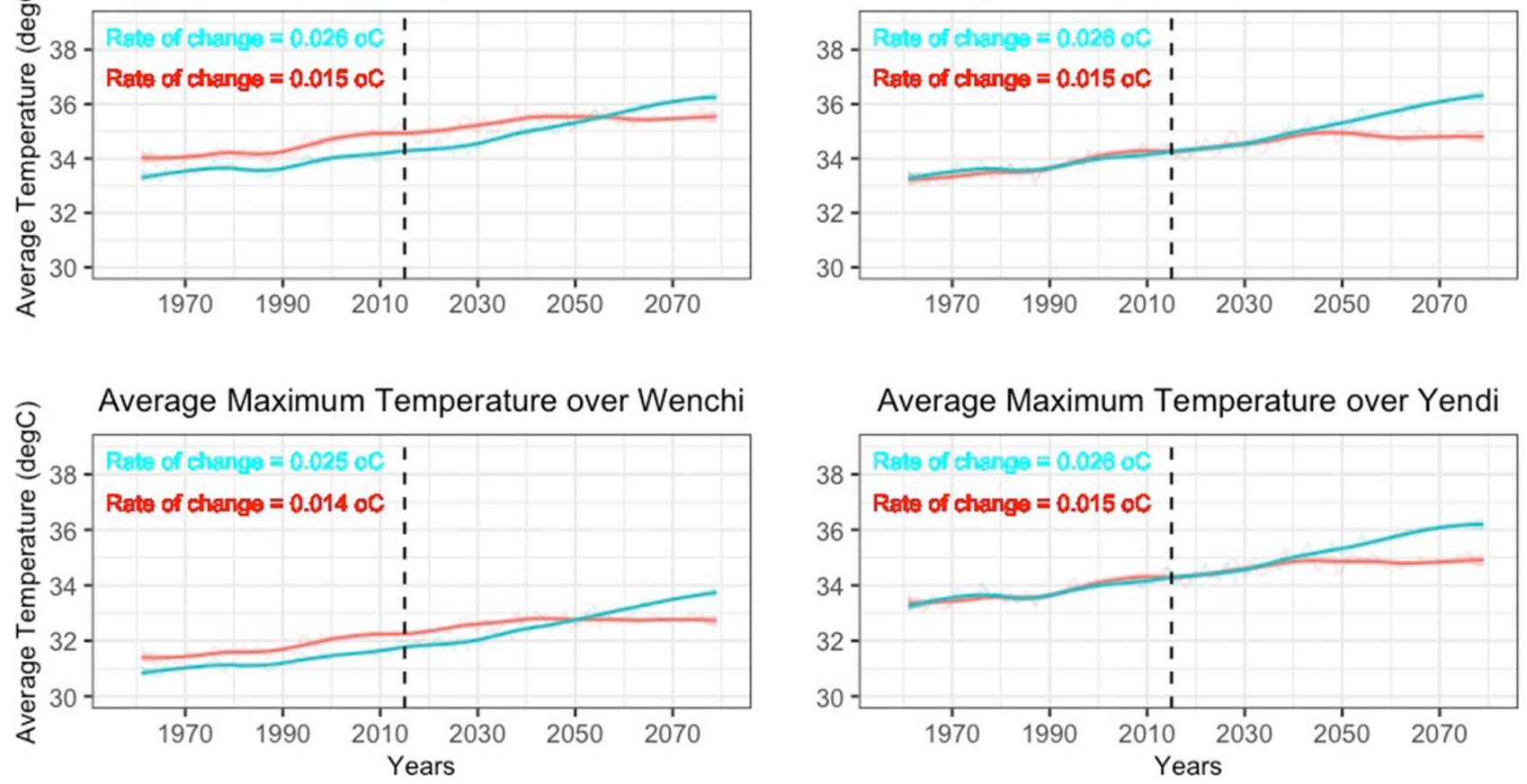

- RCP2.6_Tmax

RCP8.5_Tmax

Fig. 5 Same as Fig. 3 but for maximum temperature

national average of $0.021{ }^{\circ} \mathrm{C}$ per year and is consistent with our results. The warming rate of minimum temperature is projected to be higher than the warming rate of maximum temperature, and this is consistent across all the stations towards 2080 . This suggests that both day and night temperatures are likely to increase, but faster warming is likely to be experienced during the night time. This is an indication that residual heat of the day is increasing. 

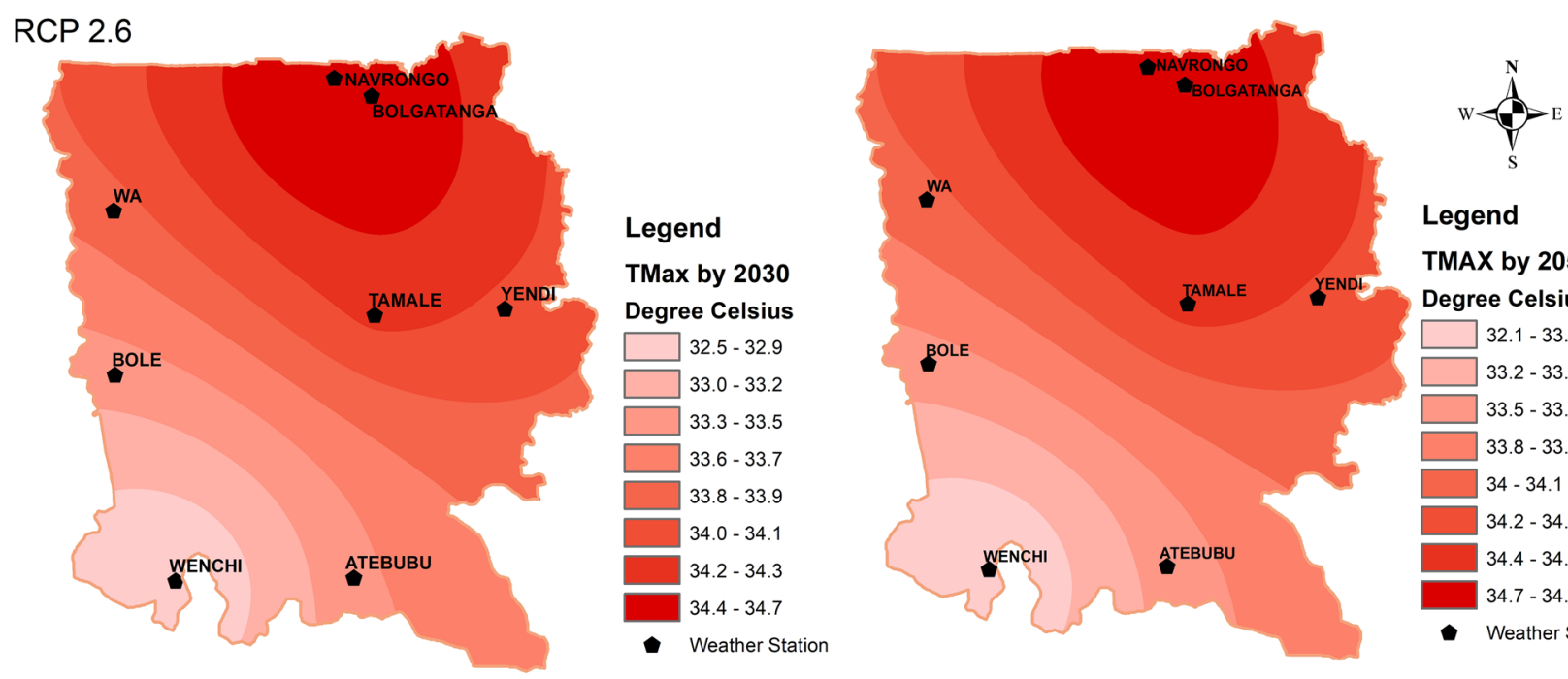

RCP 8.5
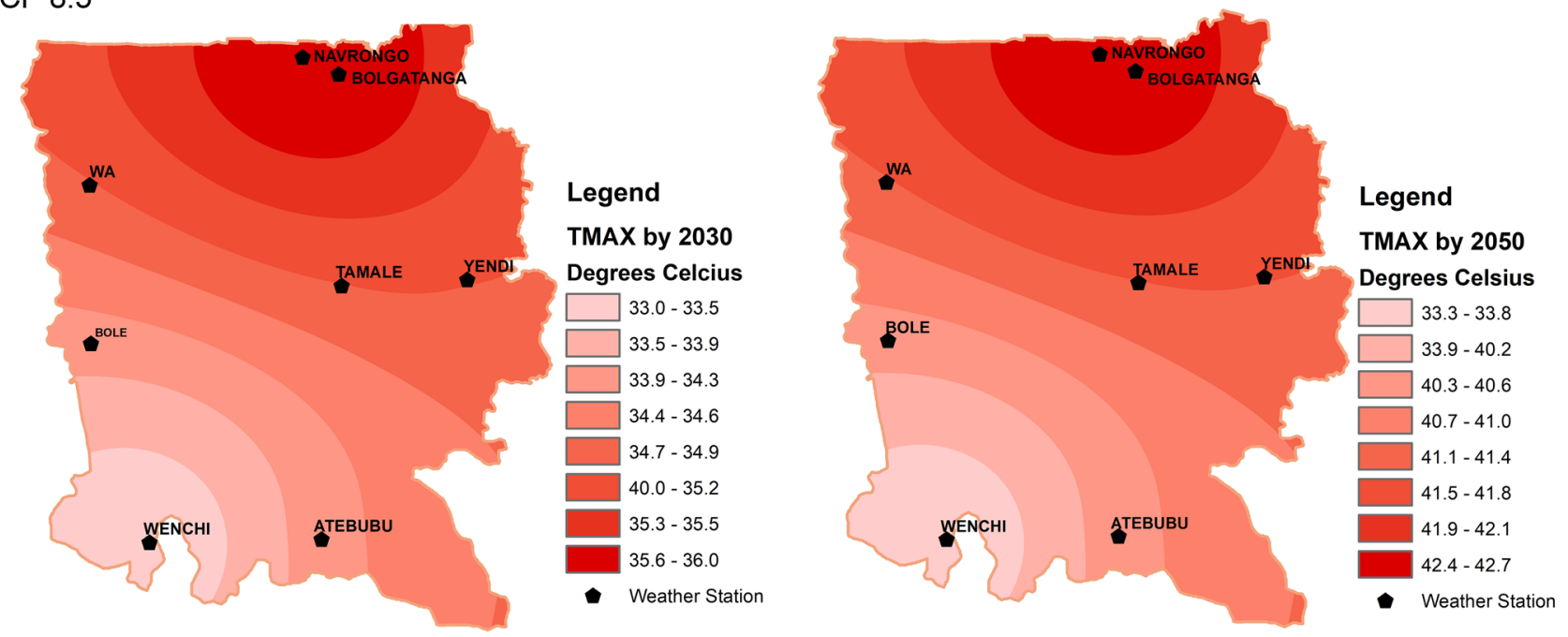

Fig. 6 Averaged maximum temperature for 2030 and 2050 in the study area on of Ghana for the RCP2.6 and RCP8.5 scenarios

\subsection{Extreme temperatures}

Ninety-ninth (99\%) percentiles of the minimum and maximum air temperatures have been computed for the period 1961-2080 and are shown in Figs. 7 and 8. The 99th percentiles represent extreme events such as heat waves. Generally, for the 99th percentile of minimum temperature for the stations (Fig. 7), each pathway has a variation between $22.5^{\circ} \mathrm{C}$ and $30^{\circ} \mathrm{C}$. Wenchi and Atebubu have the lowest value of the 99th percentile of minimum temperatures. There is a close relationship between the 99th percentiles of the minimum temperature for the RCP 2.6 and RCP 8.5 pathways in all the stations except for Wenchi, which shows a difference of about $1{ }^{\circ} \mathrm{C}$ from 1961 until 2060 , and for Bolgatanga, which shows a difference of $1{ }^{\circ} \mathrm{C}$ between the two pathways from 1961 to 2000 and after 2040.
For the 99th percentile of maximum temperatures for the stations (Fig. 8), all stations except Wenchi, Tamale and Bolgatanga start closely and show bigger differences from 2060 to 2080 . Though close, these three stations show a difference of about $1{ }^{\circ} \mathrm{C}$ from 1961 to about 2060 where Bolgatanga and Wenchi show differences of about $2{ }^{\circ} \mathrm{C}$. The lowest projected value of the 99th percentile maximum temperature is $35^{\circ} \mathrm{C}$ in Wenchi and the highest projected above $43^{\circ} \mathrm{C}$ in Navrongo. All other stations have values within the lowest in Wenchi and the highest in Navrongo. These show possibility of heat waves over the study area. Previous studies show that extreme events impact farming systems greatly [28, 39]. The high exposure to the heat during the day can undermine farm returns and overall productivity $[12,28$, 39], more so given the fact that agriculture in the study area is mainly rain dependent. The exposure can also 

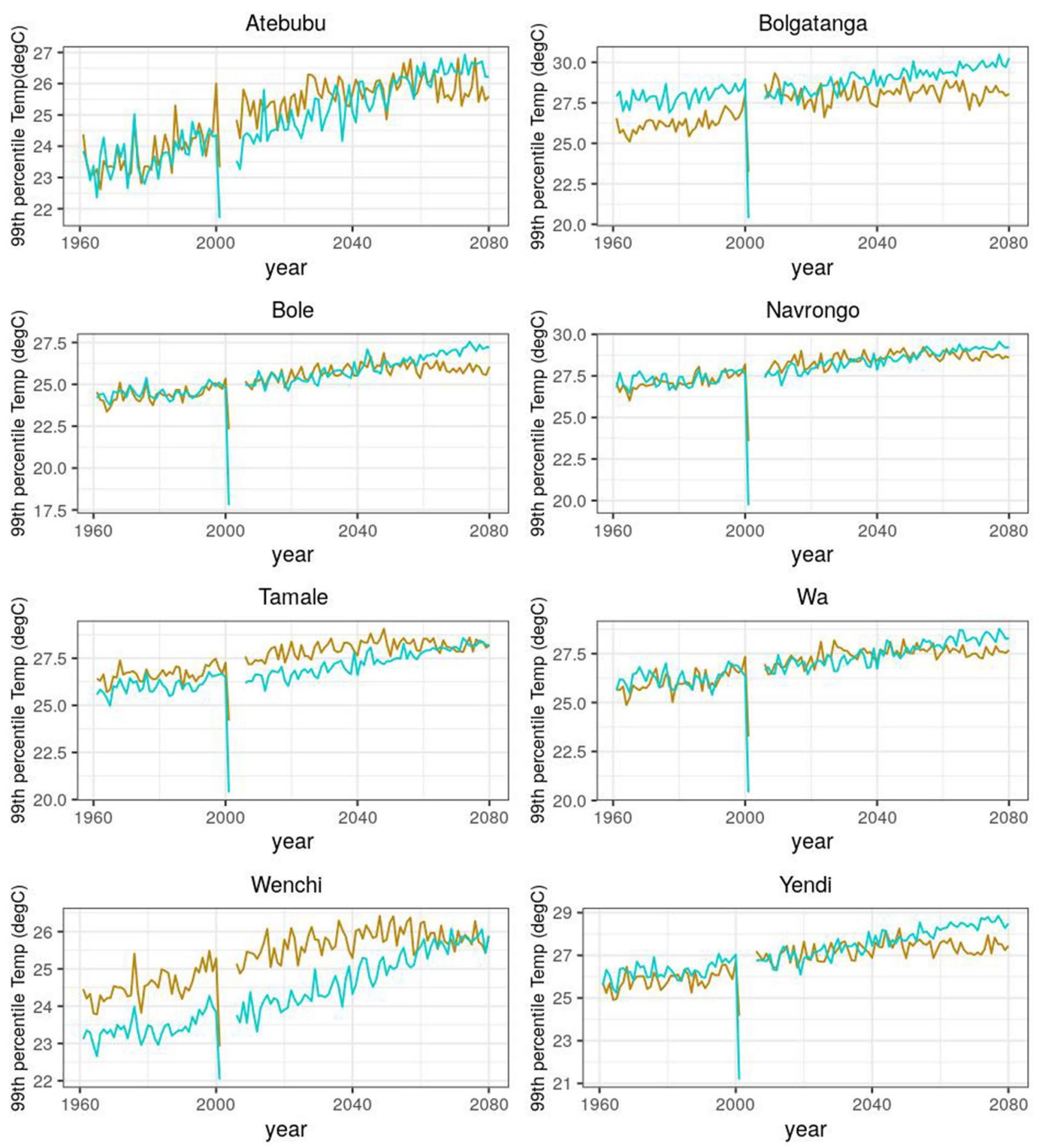

Type - RCP2.6 - RCP8.5

Fig. 7 99th percentile of minimum temperatures

be detrimental to the health of farmers; for instance, chronic dehydration can increase chronic kidney disease [4]. The sustainability of farm practices and activities including seed bed preparation, sowing, weeding and inter-cultivation as well as harvesting among smallholder farmers which is usually done manually is also under threat by extreme heat exposure. 

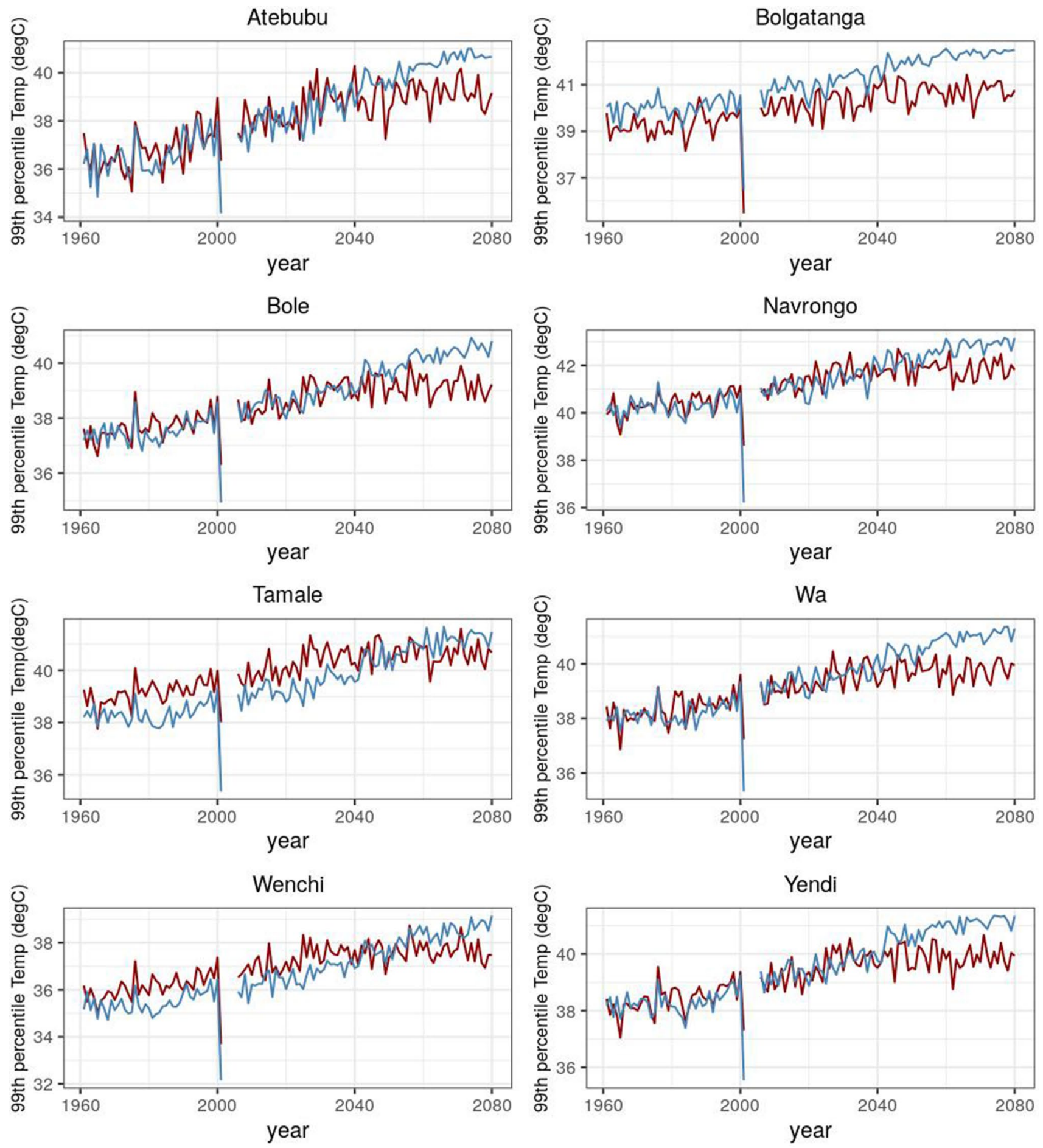

$$
\text { Type - RCP2.6 - RCP8.5 }
$$

Fig. 8 99th percentile of maximum temperature over the stations

\subsection{Implications of temperature increases on smallholder crop farming systems}

Consistent with other projections over Ghana, the rate of warming is most rapid in the northern inland regions than in the coastal regions [48]; this study shows that temperatures in the region will continue to increase into the future. Crops grown in northern Ghana are essentially 
for sustaining food supply and food security across the country [31] but could be under threat of increased crop failures due to increased $\mathrm{CO}_{2}$ levels and subsequent temperature increases. Projected extreme temperature is also likely to affect the health of farmer and increase the possibility of heat stress. The effects of temperature increase on crop productivity among smallholder farming systems although many uncertainties remain are expected to be negative. Widely cultivated food crops such as sorghum, maize, millet, cowpeas, yam and groundnuts are all expected to be negatively affected with increasing projected heat waves. Based on the study area's noted vulnerability to climate change due to existing geographical and socioeconomic conditions, food insecurity situation is expected to worsen with temperature increases under RCPs 2.6 and RCP 8.5. Studies by Barrios et al. [2], and Schlenker and Lobell [42] explicitly state that decreases in future yield of cereal crops such as maize, millet and rice due to temperature increases should be expected across sub-Sahara Africa.

The present challenge to agricultural development (which employs over $70 \%$ of the rural population) in the study area is water scarcity and drought, which is likely to be aggravated by increased evapotranspiration. Frimpong et al. [13] concluded that the agricultural sector with its high rainfed dependency will be characterized by low crop productivity as a result of increased temperatures in the absence of irrigation. Like rainfall, temperature changes are a major determinant of crop yield as it affects evapotranspiration and soil moisture content. [35] mentioned that crop production is more likely to be affected by high temperatures, especially with the limited moisture availability due to low amounts of rainfall. Additionally, they concluded that there was a negative relationship between temperature and cereal yield of smallholder farmers, which could be attributed to high temperatures across an entire growing season.

Given the low level of irrigation in Ghana and the study area specifically, increase in temperature will aggravate the already water-stressed situation and likely result in crop failures. Implicitly, the accompanying drought could cause soils to dry up further. It is, however, expected that institutional support for effective climate-related adaptation practices would be able to reduce the negative impacts of rising temperature impacts on crop production [49]. Without such practices as rainfall harvesting for irrigation and careful selection of crop varieties [36], crop yield is likely to decline.

\subsection{Conclusions and recommendation}

The study used five regional climate models (RCMs) driven by three global climate models (GCMs) in the
CORDEX experiment. Observed data from eight meteorological stations spread over northern Ghana were selected for the study based on the quality and completeness of the data. Variables considered were daily minimum and maximum temperature from the Ghana Meteorological Agency. The observed baseline distribution for the stations lies within the model distribution, but the observed baseline minimum temperature shows some outliers. The simulations were done over the period 1980-2014 with the GMet station data and projected for the emission scenarios pathways RCP 2.6 and RCP 8.5 for the selected RCMs from 1961 to 2080. Mean minimum and maximum temperatures averaged for the eight (8) stations were analysed from 1961 to 2080 and presented in time series. The results show that the northern-eastern part of Ghana is likely to have the greatest rate of change in temperature by the year 2080 . The minimum temperatures over northern Ghana are likely to increase by $0.5^{\circ} \mathrm{C}$ under RCP 2.6 and $2.5^{\circ} \mathrm{C}$ under RCP 8.5 whilst the maximum temperatures are likely to increase by $1{ }^{\circ} \mathrm{C}$ under RCP 2.6 and $2^{\circ} \mathrm{C}$ under RCP 8.5. However, Tamale and the south-western part of the study area are likely to experience warmer temperature under RCP 2.6 than RCP 8.5 until 2050, but towards 2080, the maximum temperature is projected to be warmer in RCP 8.5 than $\mathrm{RCP}$ 2.6. The minimum temperature is projected to have a faster warming rate per year than maximum temperature for all the stations towards 2080 suggesting that faster warming is likely to be experienced during the night time than in the day. Furthermore, extreme temperatures are projected to increase with 99th percentile of the minimum temperature reaching $30^{\circ} \mathrm{C}$ and that of maximum temperature reaching $43^{\circ} \mathrm{C}$ putting farming practices under threat by extreme heat exposure.

Models projecting the increase in temperatures over northern Ghana are also consistently predicting a reduction in rainfall towards $2080[26,6]$ which means that high rate of evapotranspiration is likely. Given the overreliance of rainfed agriculture by smallholder farmers, likely reduction in rainfall and high evapotranspiration will imply likely low crop yield unless measures like drought-resistant crop farming and most importantly small-scale irrigation are adopted. Considering the weak adaptive capacity of smallholder food crop farmers in the study area to climate variability and change [49], intervention strategies aimed at building and enhancing vulnerable communities and household's resilience need to be place based and integrative. Currently, government policy and investments on agricultural water management in northern Ghana should focus on community-based small-scale irrigation schemes as a way towards improving and sustaining water supply for irrigation facilities and dry season farming. 


\section{Compliance with ethical standards}

Conflict of interest On behalf of all authors, the corresponding author states that there is no conflict of interest.

\section{References}

1. Antwi-Agyei P, Fraser EDG, Dougill AJ, Stringer LC, Simelton E (2012) Mapping the vulnerability of crop production to drought in Ghana using rainfall, yield and socioeconomic data. Appl Geogr 32:324-334

2. Barrios S, Ouattara B, Strobl E (2008) The impact of climatic change on agricultural production: is it different for Africa? Food Policy 33:287-298

3. Benestad RE, Hanssen-Bauer I, Førland EJ (2007) An evaluation of statistical models for downscaling precipitation and their ability to capture long term trends. Int J Climatol: A J R Meteorol Soc 27(5):649-665

4. Crowe J, van Wendel de Joode B, Wesseling C (2008) A pilot field evaluation on heat stress in sugarcane workers in Costa Rica: what to do next? Glob Health Action 2(1):2062

5. Daron JD (2014) Regional climate messages: West Africa. Scientific report from the CARIIA Adaptation at Scale in Semi-Arid Regions (ASSAR) Project. Ottawa, Canada: CARIAA and ASSAR

6. De Pinto A, Demirag U, Haruna A, Koo J, Asamoah M (2012). Climate change, agriculture, and foodcrop production in Ghana (Policy Note 3). Retrieved from International Food Policy Research Institute website: http://www.ifpri.org/publication/ climate-changeagriculture-and-foodcrop-production-ghana

7. Donatti $\mathrm{Cl}$, Harvey $\mathrm{CA}$, Martinez-Rodriguez MR, Vignola R, Rodriguez CM (2018) Vulnerability of smallholder farmers to climate change in Central America and Mexico: current knowledge and research gaps. Clim Dev 11(3):1-23

8. Dixon J (2003) Authority, power and value in contemporary industrial food systems. Int J Soc Agric Food 11(1):31-40

9. Etwire P, Fielding D, Kahui V (2017). The impact of climate change on crop production in Ghana: a structural ricardian analysis (No. 1706)

10. FAO (2015) The economic lives of smallholder farmers. An analysis based on household data from nine countries. http://www. fao.org/3/a-i5251e.pdf 30/04/2019

11. FAO (2013) Supporting smallholder farmers in Africa. http:// www.fao.org. 23/4/2019

12. Frimpong K, van Etten EJ, Oosthuizen J, Nunfam V (2016). Heat exposure on farmers in northeast Ghana. https://www.resea rchgate.net/publication/305952342_Heat_exposure_on_farme rs_in_northeast_Ghana [Accessed Mar 23 2020]

13. Frimpong K, Oosthuizen JD, Van Etten EJ (2014) Recent trends in temperature and relative humidity in Bawku East, Northern Ghana. J Geogr Geol 6(2):69-81

14. Ghana Meteorological Agency (2019). Climatology. http:// www.meteo.gov.gh/website/index.php?option=com_conte nt\&view $=$ article\&id=62: limatology\&catid=40:feat Accessed on $22 / 10 / 2019$

15. Harvey CA, Rakotobe ZL, Rao NS, Dave R, Razafimahatratra H, Rabarijohn RH, Rajaofara H, Mackinnon JL (2014) Extreme vulnerability of smallholder farmers to agricultural risks and climate change in Madagascar. Philos Trans R Soc B: Biol Sci 369(1639):20130089

16. Hazell P, Poulton C, Wiggins S, Dorward A (2007). The future of small farms for poverty reduction and growth. 2020 Discussion paper No.42, IFPRI
17. Hewitson BC, Crane RG (1996) Climate downscaling: techniques and application. Clim Res 7(2):85-95

18. IPCC (2018) Global warming of $1.5^{\circ} \mathrm{C}$. An IPCC Special Report on the impacts of global warming of $1.5^{\circ} \mathrm{C}$ above pre-industrial levels and related global greenhouse gas emission pathways, in the context of strengthening the global response to the threat of climate change, sustainable development, and efforts to eradicate poverty [Masson-Delmotte, Zhai VP, Pörtner HO, Roberts D, Skea J, Shukla PR, Pirani A, Moufouma-Okia W, Péan C, Pidcock R, Connors S, Matthews JBR, Chen Y, Zhou X, Gomis MI, Lonnoy E, Maycock T, Tignor M, Waterfield T (eds.)]. In Press

19. IPCC (2014) Climate change 2014: impacts, adaptation, and vulnerability. Part B: regional aspects. Contribution of working group II to the fifth assessment report of the intergovernmental panel on climate change [Barros VR, Field CB, Dokken DJ, Mastrandrea MD, Mach KJ, Bilir TE, Chatterjee M, Ebi KL, Estrada YO, Genova RC, Girma B, Kissel ES, Levy AN, MacCracken S, Mastrandrea PR, White LL (eds.)]. Cambridge University Press, Cambridge, United Kingdom and New York, NY, USA, 688 pp

20. Kabo-Bah AT, Diji CJ, Nokoe K, Mulugetta Y, Obeng-Ofori D, Akpoti K (2016) Multiyear rainfall and temperature trends in the volta river basin and their potential impact on hydropower generation in Ghana. Climate 4:49

21. Kjellstrom $T$, Briggs $D$, Freyberg $C$, Lemke $B$, Otto $M$, Hyatt $O$ (2016) Heat, human performance, and occupational health: a key issue for the assessment of global climate change impacts. Annu Rev Public Health 37(1):97-112

22. Klutse NAB, Ajayi V, Gbobaniyi EO, Egbebiyi TS, Kouadio K, Nkrumah F, Quagraine KA, Olusegun C, Diasso UJ, Abiodun BJ, Lawal KAA (2018) Potential impact of $1.5^{\circ} \mathrm{C}$ and $2^{\circ} \mathrm{C}$ global warming on consecutive dry and wet days over West Africa. Environ Res Lett 13(5):055013

23. Klutse NAB, Owusu K, Adukpo DC, Nkrumah F, Quagraine $K$, Owusu A, Gutowski WJ (2013) Farmer's observation on climate change impacts on Maize (Zea mays) production in a selected agro-ecological zone in Ghana. Res J Agric Environ Manag 2(12): 394-402, ISSN 2315 - 8719@ 2013 Apex Journal International

24. Kranjac-Berisavljevic G (1999). Recent climatic trends in northern interior savannah zone of Ghana; implication for agricultural production. In: A paper presented at the international conference on integrated drought management, pp. 20-22)

25. Lodder RA, Hieftje Gary M (1988) Quantile analysis: a method for characterizing data distributions. Appl Spectrosc 42:1512-1520

26. MESTI (2015) Ghana's third national communication to the UNFCCC. Retrieved from UNFCCC website: http://unfccc.int/resou rce/docs/natc/ghanc3.pdf

27. MESTI (2012) Ghana's second national communication to the UNFCCC. Retrieved from UNFCCC website: http://unfccc.int/ resource/docs/natc/ghanc2.pdf

28. McMichael AJ, Campbell-Lendrum D, Ebi K, Githeko A, Sceraga J, Woodward A (2003) Climate change and human health: risks and responses. World Health Organization, Geneva

29. McSweeney C, New M, Lizcano G, Lu X (2010) The UNDP climate change country profiles: improving the accessibility of observed and projected climate information for studies of climate change in developing countries. Bull Am Meteorol Soc 91(2):157-166

30. Minia Z (2008) Climate change scenario development. In: Agyemang-Bonsu WK (ed) Ghana climate change impacts, vulnerability and adaptation assessments. Environ ProtAgency, Accra, pp 2-13

31. MOFA (Ministry of Food and Agriculture) (2015). Agriculture in Ghana. Facts and figures 2014. Ministry of Food and Agriculture (MoFA). Statistics, Research and Information Directorate (SRID). Accra

32. Nikulin G, Lennard CJ, Dosio A, Kjellström E, Chen Y, Hänsler A, Kupiainen M, Laprise R, Mariotti L, Maule CF, van Meijgaard E, 
Panitz H-J, Scinocca JF, Somot S (2018) The effects of 1.5 and 2 degrees of global warming on Africa in the CORDEX ensemble. Environ Res Lett 13(6):065003

33. Nikulin G, Jones C, Giorgi F, Asrar G, Büchner M, Cerezo-Mota R, Christensen $O B$, Déqué $M$, Fernandez J, Hänsler $A$, van Meijgaard E (2012) Precipitation climatology in an ensemble of CORDEXAfrica regional climate simulations. J Clim 25(18):6057-6078

34. Nyadzi E (2016) Climate variability since 1970 and farmers' observations in Northern Ghana. Sustain Agric Res 5:526-2016-37880

35. Nyuor AB, Donkor E, Aidoo R, Buah SS, Naab JB, Nutsugah SK, Bayala J, Zougmore R (2016) Economic impacts of climate change on cereal production: implications for sustainable agriculture in Northern Ghana. Sustainability 8(8):724

36. Owusu K (2018) Rainfall changes in the savannah zone of northern Ghana 1961-2010. Weather 73(2):46-50. https://doi. org/10.1002/wea.2999

37. Owusu K, Asiedu AB, Yankson PWK, Ntiamoa-Baidu Y (2013) An assessment of climate and climate change content of courses and research at the University of Ghana. NCTE Tert Educ Ser 6(1):1-12

38. Owusu K, Klutse NAB (2013) Simulation of the Rainfall Regime over Ghana from CORDEX. Int J Geosci 4:785-791

39. Sahu S, Sett M, Kjellstrom T (2013) Heat exposure, cardiovascular stress and work productivity in rice harvesters in India: implications for a climate change future. Ind Health 51(4):424-431

40. Saito O, Kranjac-Berisavljevic G, Takeuchi K, Gyasi EA (2018) Strategies for building resilience against climate and ecosystem changes in sub-saharan Africa. Springer, Berlin. https://doi. org/10.1007/978-981-10-4796-1

41. Sanchez PA, Swaminathan MS (2005) Hunger in Africa: the link between unhealthy people and unhealthy soils. Lancet 365(9457):442-444

42. Schlenker W, Lobell DB (2010) Robust negative impacts of climate change on African agriculture. Environ Res Lett 5:1-8

43. Stanturf JA, Warren ML, Charnley S, Polasky SC, Goodrick SL, Armah F, Nyako YA (2011) Ghana climate change vulnerability and adaptation assessment. United States Agency for International Development, Washington

44. Steynor A, Pasquini L (2019) Informing climate services in Africa through climate change risk perceptions. Clim Serv 15:100112

45. Sylla MB, Nikiema PM, Gibba P, Kebe I, Klutse NAB (2016) Climate change over West Africa: recent trends and future projections. In: Yaro J, Hesselberg J (eds) Adaptation to climate change and variability in rural West Africa. Springer, Cham https://doi.org/10.1007/978-3-319-31499-0_3 Online ISBN 978-3-319-31499-0

46. UNEP (2013) Smallholders, food security and the environment. United Nations Environment Programme/International Fund for Agricultural Development (IFAD), Rome

47. UNFCCC (2015) INDCs as communicated by parties (www4. unfccc.int/submissions/indc/Submission\%20Pages/submission s. aspx) (Accessed 18 October 2019)

48. World Bank (2010) Economics of adaptation to climate change. Ghana country study. World Bank, Washington, DC

49. Yaro JA, Teye J, Bawakyillenuo S (2015) Local institutions and adaptive capacity to climate change/variability in the northern savannah of Ghana. Clim Dev 7(3):235-245

50. Yiran GAB, Stringer LC (2016) Spatio-temporal analyses of impacts of multiple climatic hazards in a savannah ecosystem of Ghana. Clim Risk Manag 14:11-26. https://doi.org/10.1016/j. crm.2016.09.003

51. Zhang X, Yang F (2004). RClimDex (1.0) user manual. Climate Research Branch Environment Canada, 22

Publisher's Note Springer Nature remains neutral with regard to jurisdictional claims in published maps and institutional affiliations. 